\title{
Upregulation of soluble vascular endothelial growth factor receptor type 1 by endogenous prostacyclin inhibitor coupling factor 6 in vascular endothelial cells: a role of acidosis-induced c-Src activation
}

\author{
Takashi Echizen ${ }^{1}$, Tomohiro Osanai ${ }^{1}$, Toshihiro Ashitate ${ }^{1}$, Hiroaki Yokoyama ${ }^{1}$, Shuji Shibutani ${ }^{1}$, \\ Makoto Tanaka ${ }^{1}$, Hirofumi Tomita ${ }^{1}$, Koji Magota ${ }^{2}$ and Ken Okumura ${ }^{1}$
}

Vascular endothelial growth factor (VEGF) is a well-known promoter of angiogenesis, but its receptor VEGFR-1 and a soluble short form of VEGFR-1 (sFIt-1) play a negative role in the VEGF signal pathway by trapping VEGF. We recently showed that endogenous prostacyclin inhibitor coupling factor 6 (CF6) forces the clockwise rotation of $F_{1}$ motor of plasma membrane adenosine triphosphate synthase and induces intracellular acidosis and c-Src activation. We investigated the role of CF6 in regulation of sFIt-1, and its mechanism in human umbilical vein endothelial cells. The ratio of sFIt-1 to glyceraldehyde 3-phosphate dehydrogenase mRNA was increased at $24 \mathrm{~h}$ by $1.59 \pm 0.29$-fold by $10^{-7} \mathrm{M}$ CF6 $(P<0.05)$, concomitantly with the increases in intercellular adhesion molecule- 1 and lectin-like oxidized low-density lipoprotein receptor- 1 and no change in VEGF-A. When the dose of CF6 was increased to $10^{-6} \mathrm{M}$, no further increase in sFIt-1 mRNA was observed. The release of sFlt-1 protein was increased by $1.72 \pm 0.24$-fold $(P<0.05)$ at $48 \mathrm{~h}$ after exposure to $\mathrm{CF} 6$ at $10^{-7} \mathrm{M}$, and it was blocked by pretreatment with anti-CF6 antibody. The immunoreactive bands for sFlt-1 and VEGFR-1 were both increased by CF6 to similar degrees. Pretreatment with PP1, an inhibitor of $\mathrm{c}$-Src, and $10^{-5} \mathrm{M}$ efrapeptin, an inhibitor of $\mathrm{F}_{1}$ motor, inhibited CF6-induced increases in expression and release of sFIt-1 $(P<0.05)$. In mice overexpressing CF6, the plasma level of sFIt-1 was increased by $1.36 \pm 0.29$-fold compared with that in wild-type mice $(P<0.05)$. These indicate that CF6 might increase the expression and release of sFIt-1 in the vessels through acidosis-induced c-Src activation.

Hypertension Research (2009) 32, 182-187; doi:10.1038/hr.2008.24; published online 16 January 2009

Keywords: prostacyclin inhibitor; Flt-1; sFIt-1; atherosclerosis

\section{INTRODUCTION}

Nitric oxide (NO) and prostacyclin are recognized as the major mediators for maintenance of vascular homeostasis, and the decrease in $\mathrm{NO}$ and prostacyclin release is implicated in endothelial dysfunction. Vascular endothelial growth factor (VEGF) is a well-known promoter of angiogenesis. It also induces the generation of $\mathrm{NO}$ and prostacyclin in vascular endothelial cells, suggesting a role for VEGF in the regulation of vascular homeostasis. ${ }^{1,2}$ VEGF receptor-1 (VEGFR-1), a member of the VEGFR family, binds to VEGF-A, placental growth factor and VEGF-B. An important feature of VEGFR-1 is that, unlike other VEGFR genes, it expresses two types of mRNA, one for a fulllength receptor and another for a soluble short protein known as soluble VEGFR-1 (sFlt-1). The binding affinity of VEGFR-1 for VEGF$\mathrm{A}$ is higher than that of VEGFR-2, whereas the kinase activity of VEGFR-1 is weaker than that of VEGFR-2. ${ }^{3}$ Therefore VEGFR-1, especially sFlt-1, plays a negative role in the VEGF signal pathway by trapping the ligand, whereas VEGFR-2 plays a positive role. Overexpression of sFlt-1 was first shown in the placenta of pre-eclamptic patients, and it was suggested to cause the major pathological symptoms such as hypertension and renal dysfunction. Although the factors regulating the synthesis and secretion of sFlt-1 during pregnancy are largely unknown, hypoxia has been shown to increase sFlt-1 production in placental cytotrophoblasts. ${ }^{4}$ Angiotensin II (Ang II), a representative proatherogenic molecule, was also reported to induce synthesis and secretion of sFlt-1 by nonhypoxic induction of the hypoxia-inducible transcription factor- $\alpha$ through $\mathrm{AT}_{1}$ receptor pathways, but it was observed only in human trophoblasts, not in vascular endothelial cells. ${ }^{5,6}$

We recently showed that coupling factor 6 (CF6), a component of adenosine triphosphate (ATP) synthase, is present in the systemic

${ }^{1}$ Department of Cardiology, Hirosaki University Graduate School of Medicine, Hirosaki, Japan and ${ }^{2}$ Asubio Pharma Co., Ltd., Biomedical Center, Biopharma Research Department, Biotechnology Group, 2716-1, Kurakake, Akaiwa, Chiyoda-machi, Ohra-gun, Gunma-ken, Japan 
circulation ${ }^{7}$ and suppresses prostacyclin generation through inhibition of cytosolic phospholipase $\mathrm{A}_{2}{ }^{8}$ and NO generation by upregulating asymmetric dimethylarginine, an endogenous competitive inhibitor of NO synthase. ${ }^{9}$ It is of interest that the molecular rotary motor $\mathrm{F}_{1} \mathrm{~F}_{0}$ complex, ATP synthase, is present in the plasma membrane, ${ }^{10,11}$ and that endogenous prostacyclin and NO inhibitor CF6 forces the backward rotation of $\mathrm{F}_{0}$ motor after binding to $\mathrm{F}_{1}$ motor at the plasma membrane, resulting in intracellular acidosis. ${ }^{12}$ This signal is clearly distinct from that of other proatherogenic molecules, such as Ang II, that induce intracellular alkalosis by activation of sodium hydrogen exchanger after binding to each receptor. It is noted that intracellular acidosis is easily caused by hypoxia, and hypoxia is well known to be associated with stimulation of sFlt-1 release. ${ }^{4}$ We therefore tested the hypothesis that CF6 upregulates sFlt-1 generation and increase by acidosis-induced c-Src activation in the vascular endothelial cells.

\section{MATERIALS AND METHODS}

\section{Materials}

The HuMedia-EG2 kit was purchased from Kurabo Co. Ltd, Osaka, Japan. The QIAamp RNA kit was purchased from QIAGEN (Tokyo, Japan). Human sFlt-1, VEGFR-2 and glyceraldehyde 3-phosphate dehydrogenase (GAPDH) primers, TaqMan probe and TaqMan Gold reverse transcriptase (RT)-PCR kit were obtained from Applied Biosystems (Foster City, CA, USA). Human CF6 was purchased from Phoenix Pharmaceuticals Inc. (Belmont, CA, USA). sFlt-1 enzyme-linked immunosorbent assay (ELISA) kits for human and mouse were purchased from R\&D systems Inc. (Minneapolis, MN, USA). Antibodies for human VEGFR-1 and GAPDH were obtained from Santa Cruz Biotechnology (Santa Cruz, CA, USA). PP1, a specific inhibitor of c-Src, was purchased from Biomol International LP (Plymouth Meeting, PA, USA). Polyvinilidene difluoride membrane was from Bio-Rad Laboratories (Hercules, CA, USA). Enhanced chemiluminescence plus detection systems were from Amersham Pharmacia Biotech (Piscataway, NJ, USA). All other reagents were of the finest grade available from Sigma Chemical Co. (St Louis, MO, USA).

\section{Cell culture}

Human umbilical vein endothelial cells (HUVEC) were cultured in HuMediaEG2 (complete media) at $37^{\circ} \mathrm{C}$ under $5 \% \mathrm{CO}_{2}$. HUVEC from the second to sixth passage were used for the study. After treatment with various molecules, the viability of the cells, which was determined by Trypan blue excretion, was generally $>95 \%$.

\section{Construction of vectors and generation of transgenic mice}

A gene for the N-terminal portion of human calcitonin (Met 1-Arg 84) was fused to a gene for the mature ATP synthase CF6 (Asn 33-Ala 108). The fused gene was subcloned into pNE plasmid, in which the globin promoter of pdKCR-dhfr plasmid ${ }^{13}$ was replaced by human elongation factor $1 \alpha$ promoter. The resultant recombinant plasmid was digested with PvuII and Aor51HI to generate $2.8 \mathrm{~kb}$ of DNA fragment consisting of the human elongation factor $1 \alpha$ promoter, human calcitonin/CF6 fused gene and SV40 polyA additional sequence. The DNA fragment was then microinjected into the pronuclei of single-cell fertilized mouse embryos to generate TG mice. By using COS cells it was confirmed that the expressed fusion protein was released outside of the cells in the form of mature human CF6 (Asn33-Ala108) after cleavage.

Two lines of homozygous TG mice were produced. The gene expression of CF6 mRNA was increased by twofold in overall tissues in both lines of TG mice. All animals were maintained in the same environment, at the same temperature and humidity and with free access to food and water. Systolic arterial blood pressure at baseline, which was measured by the tail-cuff method under consciousness, was increased in one line of TG mice compared with wild-type (WT) mice aged 15-20 weeks ( $120 \pm 5$ vs. $110 \pm 3 \mathrm{~mm} \mathrm{Hg}, P<0.05)$, but not in another line. All experiments were conducted in TG mice and WT mice aged 10-12 weeks.

\section{Protocol}

Human umbilical vein endothelial cells were treated with CF6 at $10^{-7} \mathrm{M}$ for 24 or $48 \mathrm{~h}$ with or without various inhibitors for signaling. Further the cells' gene expression of sFlt-1 and VEGFR-2, and the concentration of sFlt-1 in the culture media were measured using real-time RT-PCR or the ELISA kit. The culture supplemented with various inhibitors was incubated for $15 \mathrm{~min}$ before the experiments. In another experiment, the concentration of sFlt-1 in the culture media was measured using the ELISA kit after pretreatment with antiCF6 antibody (1:1000 dilution).

\section{Determination of gene expression}

Total RNA was extracted from the cells using the QIAamp RNA kit. A two-step RT-PCR was carried out according to the protocol supplied with the TaqMan Gold RT-PCR kit. The standard curves of sFlt-1, VEGF-A, intercellular adhesion molecule-1 (ICAM-1), oxidative stress-related genes such as lectinlike oxidized low-density lipoprotein receptor-1 (LOX-1), and GAPDH were linear between 0.1 and $250 \mathrm{ng}^{-1} \mathrm{l}^{-1}$ total RNA. Values were averaged from duplicate data and normalized with the human GAPDH.

Quantification of sFlt-1 protein in cell culture media and plasma The concentrations of human sFlt-1 in the cell culture supernates and mouse sFlt-1 in the plasma were measured using the specific commercial sandwich ELISA kit according to the manufacturer's protocols.

\section{Western blot for VEGFR-1 and sFlt-1 proteins}

Tissue and cell samples were homogenized in RIPA lysis buffer $\left(20 \mathrm{mmoll}^{-1}\right.$ Tris-HCl, pH 7.5, $150 \mathrm{mmoll}^{-1} \mathrm{NaCl}, 1 \mathrm{mmoll}^{-1}$ EDTA, 1 mmoll ${ }^{-1}$ EGTA, $1 \%$ Triton X-100, $1 \%$ glycerol, $1 \mathrm{mmoll}^{-1}$ dithiothreitol and $0.5 \mathrm{mmoll}^{-1}$ phenylmethylsulfonyl fluoride). Supernate samples were partially purified by Sep-Pak C18 cartridges. Protein concentrations of cell lysates and concentrated supernates were determined by the Bradford method. Samples were then mixed with Laemelli buffer containing $5 \% \beta$-mercaptoethanol, and were evenly loaded onto SDS-polyacrylamide gel electrophoresis. The protein was transferred electrophoretically to a polyvinilidene difluoride membrane. After blocking for $1 \mathrm{~h}$, the membranes were incubated with the primary antibody for VEGFR1 and GAPDH at $4{ }^{\circ} \mathrm{C}$ overnight. The protein bands for antigen-antibody complexes were detected by the enhanced chemiluminescence plus detection systems. Densitometric analysis was performed using Scion image software, and the ratio relative to the protein bands was calculated for each sample.

\section{Statistics}

All data are shown as mean \pm 1s.e.m. One-way analysis of variance for multiple comparisons followed by Bonferroni's test was used for statistical analysis. The level of significance was less than 0.05 .

\section{RESULTS}

\section{Effects of CF6 on gene expression of sFlt-1}

As shown in Figure 1a, the ratio of sFlt-1 to GAPDH mRNA by realtime quantitative RT-PCR was increased at $24 \mathrm{~h}$ by $1.59 \pm 0.29$-fold $(P<0.05)$ using $10^{-7} \mathrm{M}$ CF6 and returned to the baseline at $48 \mathrm{~h}$. As shown in Figure 1b, the ratios of sFlt-1 to GAPDH mRNA were increased in a dose-dependent manner after 24-h exposure to CF6 $(P<0.05$, one-way analysis of variance). When the dose of CF6 was increased to $10^{-6} \mathrm{M}$, no further increase in sFlt-1 mRNA was observed (Figure 1b). Figure 1c shows the effects of CF6 at $10^{-7} \mathrm{M}$ with or without PP1, an inhibitor of c-Src, and efrapeptin, an inhibitor of ATPase, on the ratios of sFlt-1 to GAPDH mRNA. Pretreatment with PP1 inhibited CF6-induced increase in gene expression of sFlt-1 $(P<0.05)$. Efrapeptin at $10^{-5} \mathrm{M}$ also dampened CF6-induced increase in gene expression of sFlt-1 $(P<0.05)$. As shown in Figure 1d, CF6 at $10^{-7} \mathrm{M}$ did not affect the gene expression of VEGFR-2 and VEGF-A, but increased the expression of ICAM-1 and LOX-1. As reported previously, ${ }^{12} \mathrm{CF} 6$ at $10^{-7} \mathrm{M}$ activated ATPase activity at the surface of vascular endothelial cells and led to intracellular acidosis, resulting in 

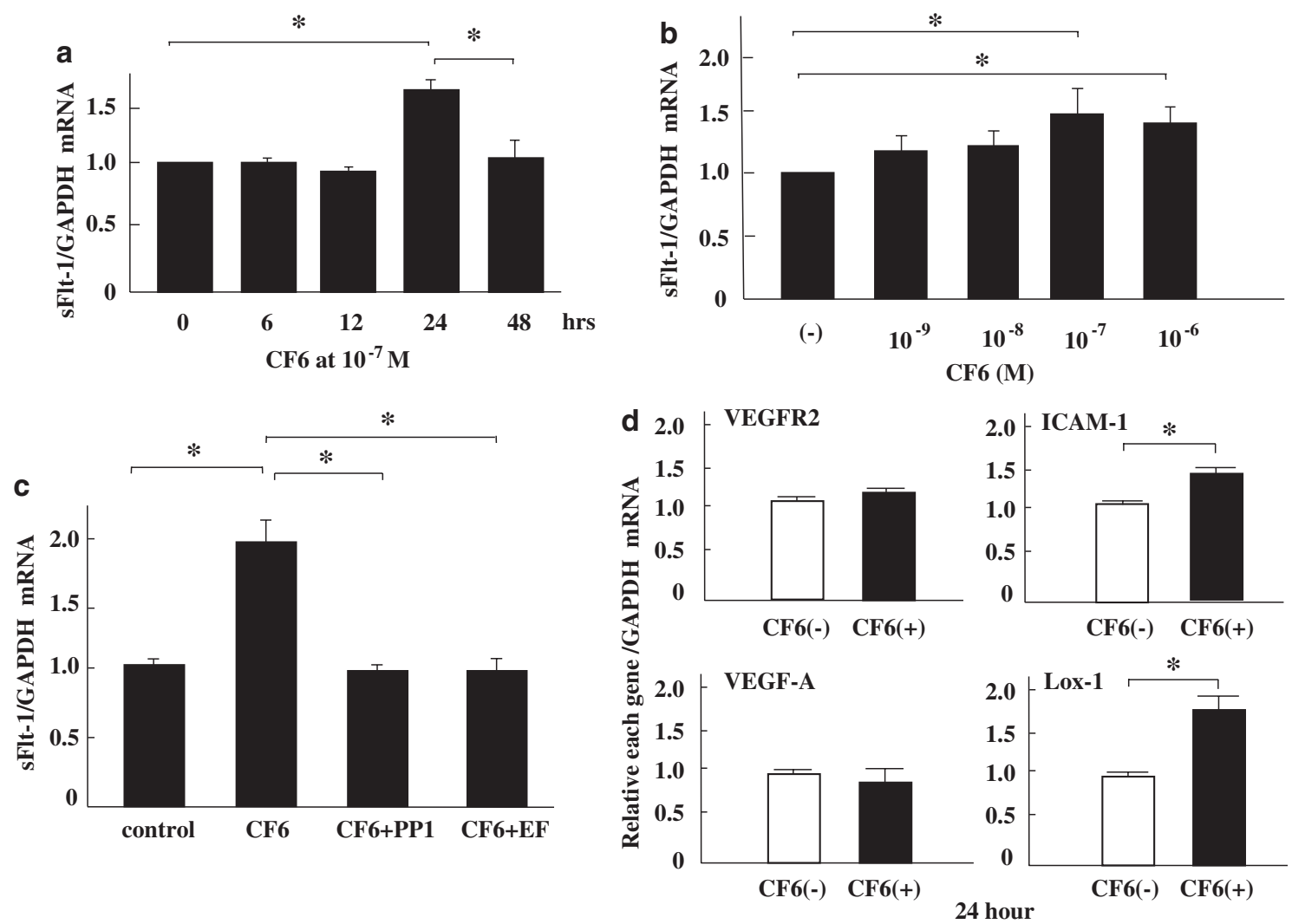

Figure 1 Effects of human coupling factor 6 (CF6) on the gene expression of sFlt-1 and vascular endothelial growth factor receptor-2 (VEGFR-2) in human umbilical vein endothelial cells. (a) Chronological changes after exposure to CF6 at $10^{-7} \mathrm{M}(n=6)$. ${ }^{*} P<0.05$. (b) Dose-related changes after $24-\mathrm{h}$ exposure to CF6 at $10^{-9}-10^{-6} \mathrm{M}(n=3-7)$. ${ }^{*} P<0.05$. (c) Effects of CF6 on the ratios of sFlt-1 to glyceraldehyde 3-phosphate dehydrogenase (GAPDH) mRNA at $24 \mathrm{~h}$ and effects of various compounds on CF6-induced increase in sFlt- 1 gene expression $(n=4-6)$. ${ }^{*} P<0.05$. Control (without agonists), CF6 at $10^{-7} \mathrm{M}, \mathrm{PP} 1$ at $50 \mu \mathrm{m}$, EF: efrapeptin at $10^{-5} \mathrm{M}$. (d) Effect of CF6 on the ratios of VEGFR-2, vascular endothelial growth factor (VEGF)-A, intercellular adhesion molecule-1 (ICAM-1) and lectin-like oxidized low-density lipoprotein receptor-1 (LOX-1) to GAPDH mRNA at $24 \mathrm{~h}$.

activation of c-Src. Efrapeptin blocked CF6-induced intracellular acidosis and c-Src activation, whereas PP1 blocked c-Src activation without affecting induction of intracellular acidosis (data not shown).

\section{Effects of CF6 on sFlt-1 protein release}

As shown in Figure 2a, the release of sFlt-1 protein in the supernate was increased in a time-dependent manner (both $P<0.05$, one-way analysis of variance). $\mathrm{CF} 6$ at $10^{-7} \mathrm{M}$ enhanced the release of sFlt-1 protein, and the level at $48 \mathrm{~h}$ was significantly increased by $1.72 \pm 0.24$ fold $(P<0.05)$ compared with control. When the dose of CF6 was increased to $10^{-6} \mathrm{M}$, no further increase in the release of sFlt- 1 was observed (Figure 2b). Figure $2 \mathrm{c}$ shows the effect of CF6 at $10^{-7} \mathrm{M}$ with or without PP1 and efrapeptin on the release of sFlt-1 protein in HUVEC. Pretreatment with PP1 inhibited CF6-induced increase in the release of sFlt-1 protein $(P<0.05)$ without affecting its basal release (PP1(-) $221 \pm 7$ vs. $\left.\mathrm{PP} 1(+) 200 \pm 4 \mathrm{pg} \mathrm{ml}^{-1}, P=\mathrm{NS}\right)$. Efrapeptin at $10^{-5} \mathrm{M}$ also dampened CF6-induced increase in the release of sFlt-1 protein $(P<0.05)$ without affecting its basal release (efrapeptin (-) $221 \pm 7 v$ s. efrapeptin (+) $213 \pm 4 \mathrm{pg} \mathrm{ml}^{-1}, P=\mathrm{NS}$ ). As shown in Figure 2d, pretreatment with anti-CF6 antibody inhibited CF6induced increase in the release of sFlt-1 protein $(P<0.05)$ without affecting its basal release.

\section{Effects of CF6 on sFlt-1 and VEGFR-1 proteins}

Figure $3 \mathrm{a}$ illustrates the representative bands for sFlt-1 and VEGFR-1 proteins in the presence or absence of CF6 at $10^{-7} \mathrm{M}$ for $48 \mathrm{~h}$. The immunoreactive bands for sFlt-1 at $60 \mathrm{kDa}$ and VEGFR-1 at $180 \mathrm{kDa}$ were both increased after treatment with CF6 to similar degrees. As shown in Figure 3b, the ratios of sFlt-1 and VEGFR-1 to GAPDH protein were increased by $52 \pm 13$ and $60 \pm 11 \%$, respectively, in HUVEC (both $P<0.05$ ).

\section{Plasma concentration of sFlt-1 in TG mice}

As shown in Figure 4, the plasma level of sFlt-1 was increased in TG mice than in WT mice $\left(5.23 \pm 0.58\right.$ vs. $3.83 \pm 0.86 \mathrm{ng} \mathrm{m}^{-1}$, $P<0.05)$.

\section{DISCUSSION}

CF6 increases expression and release of sFlt-1

sFlt-1 protein is upregulated by hypoxia through hypoxia-inducible transcription factor- $\alpha$ in the trophoblasts. ${ }^{14-16}$ Ang II, a representative proatherogenic molecule, was also reported to induce the synthesis and secretion of sFlt-1 by nonhypoxic induction of hypoxia-inducible transcription factor- $\alpha$ through $\mathrm{AT}_{1}$ receptor pathways, ${ }^{5,6}$ but it was observed only in human trophoblasts, and not in vascular endothelial cells. We recently showed that CF6 suppresses prostacyclin and NO generation, and that its effect is mediated by intracellular acidosis. ${ }^{11}$ As intracellular acidosis is easily caused by hypoxia, and hypoxia is the only known stimulator of sFlt-1, we investigated the role of CF6 in the expression of sFlt-1. As expected, the results showed that CF6 significantly increased the gene and protein expression of sFlt-1 in HUVEC, but it was not remarkable. We therefore investigated whether 

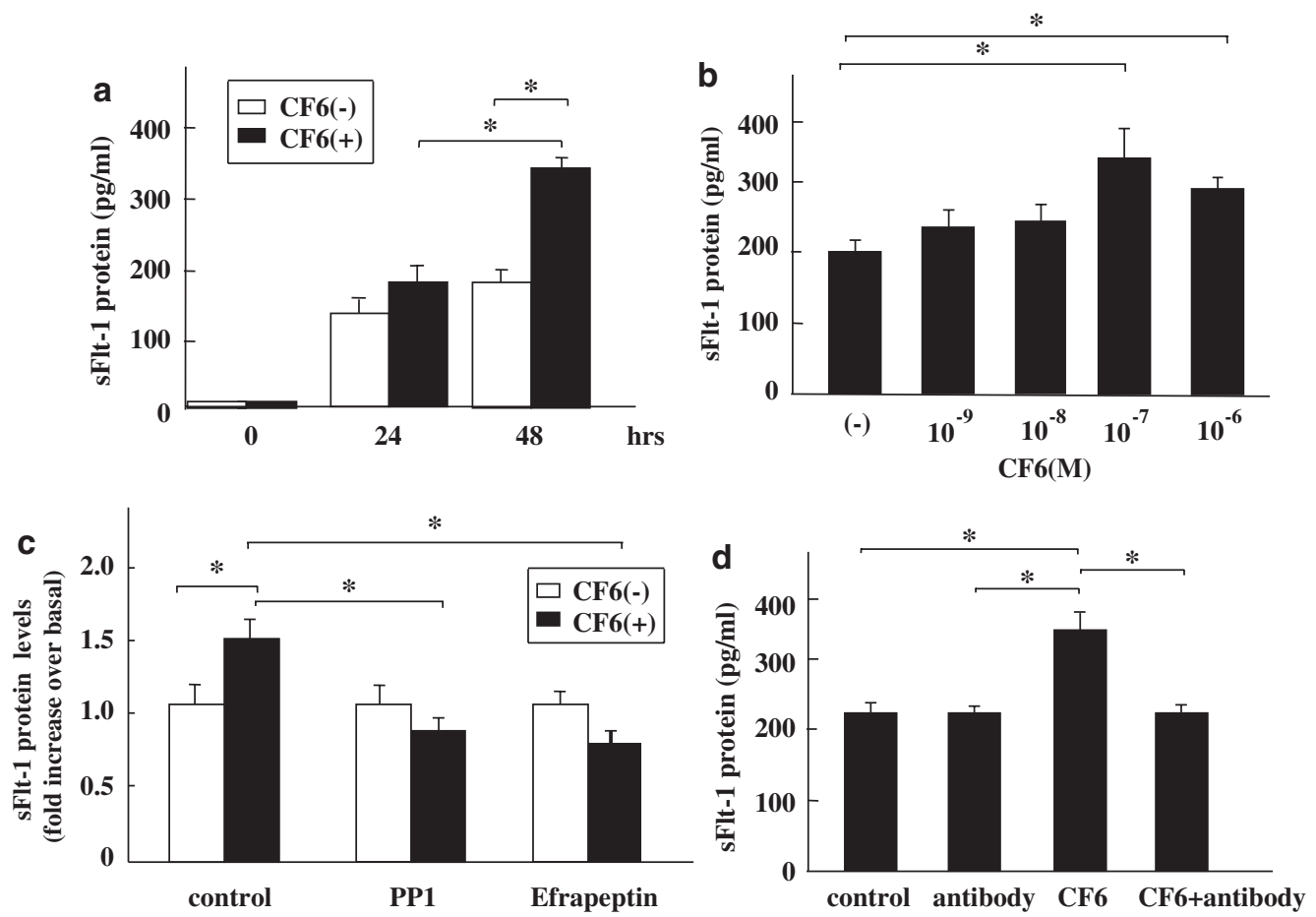

Figure 2 Effects of human coupling factor 6 (CF6) on the release of sFlt-1 protein in human umbilical vein endothelial cells. (a) Chronological changes after exposure to $10^{-7} \mathrm{M}$ CF6 $(n=6)$. ${ }^{*} P<0.05$. (b) Dose-related changes after 48-h exposure to $10^{-9}$ to $\left.10^{-6} \mathrm{M} \mathrm{CF6} \mathrm{(} n=6-8\right)$. ${ }^{*} P<0.05$. (c) Effects of various

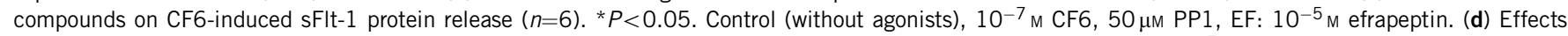
of anti-CF6 antibody on CF6-induced sFlt-1 protein release $(n=6)$. ${ }^{*} P<0.05$. Control (without anti-CF6 antibody), $10^{-7} \mathrm{M}$ CF6, anti-CF6 antibody $(1: 1000$ dilution).

a
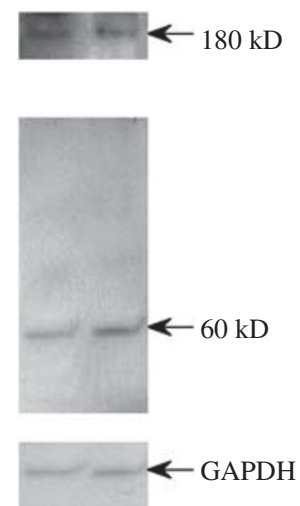

CF6 (-) (+) b

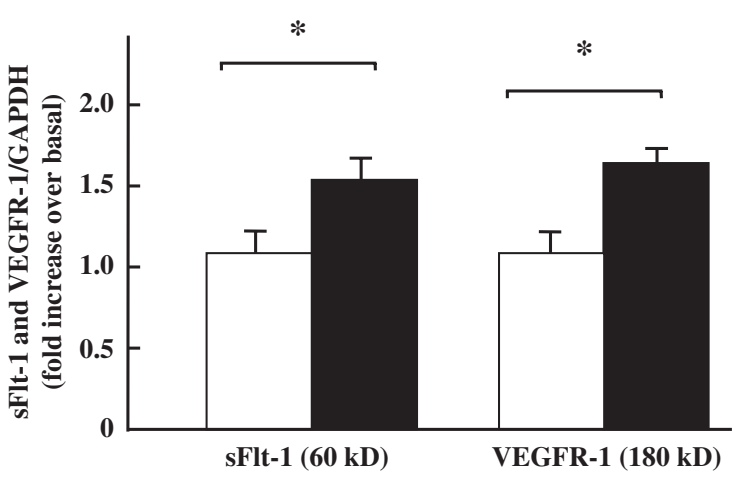

Figure 3 Effects of human coupling factor 6 (CF6) on the expression of sFIt-1 and vascular endothelial growth factor receptor-1 (VEGFR-1) protein in human umbilical vein endothelial cells. (a) Representative bands for sFIt-1 and VEGFR-1 after 48-h exposure to $10^{-7} \mathrm{M} \mathrm{CF6.} \mathrm{(b)} \mathrm{Ratios} \mathrm{of} \mathrm{sFIt-1} \mathrm{and} \mathrm{VEGFR-1} \mathrm{to}$ glyceraldehyde 3-phosphate dehydrogenase (GAPDH) protein after 48-h exposure to $10^{-7} \mathrm{M}$ CF6 $(n=4)$.

this increase in sFlt-1 affects the gene expression of ICAM-1 and LOX-1. We found that CF6 at $10^{-7} \mathrm{M}$ increased the expression of ICAM-1, which is related to the vascular endothelial function and the oxidative stress-related gene LOX-1. We further showed that CF6 suppressed endothelial NO synthase activity by increasing release of asymmetric dimethylarginine and decreasing phosphorylation at Ser ${ }^{1177}$.9,17 These observations suggest that CF6 affects the endothelial function through various mechanisms, and that the CF6-induced increase in sFlt-1 is operative to the cells in the present culture condition.
sFlt-1 and VEGFR-1 proteins are derived from alternative splicing of the same mRNA, and this process has been identified as a key regulatory step in production of sFlt-1. ${ }^{18}$ Both VEGFR-1 and sFlt-1 proteins were proportionally increased in HUVEC stimulated with CF6. Therefore, it is reasonable to presume that upregulation of sFlt-1 does not occur at the level of alternative splicing but at the level of transcription or mRNA stability. It is of importance that CF6 did not affect the gene expression of VEGF-A. Therefore, the ratio of sFlt- 1 to VEGF-A seems to be increased by CF6, thereby resulting in the progression of atherosclerosis. 


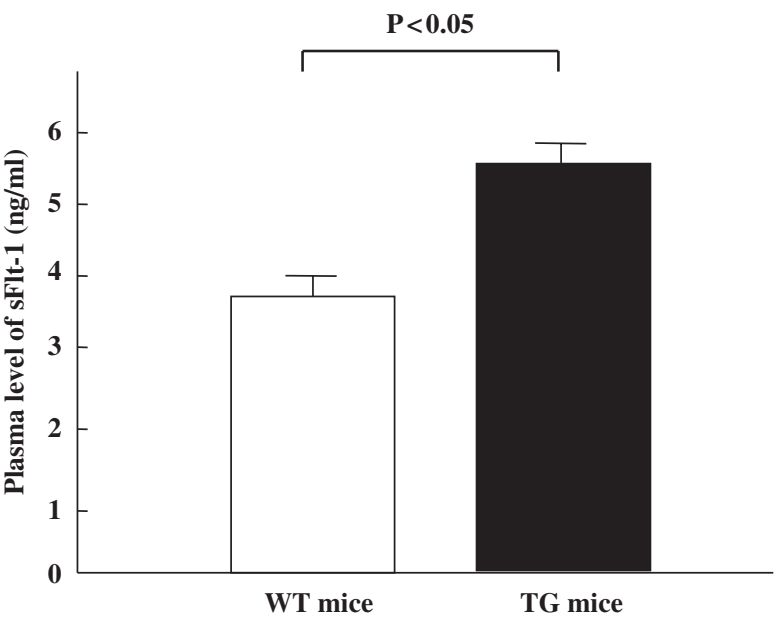

Figure 4 Plasma level of sFlt-1 in transgenic (TG) mice and wild-type (WT) mice.

The present results show that CF6 increased the gene and protein expression of sFlt-1, but it was significant only at concentrations $>10^{-7} \mathrm{M}$. Similar to other vasoactive substances, the plasma level of CF6 $\left(10^{-9}-10^{-8} \mathrm{M}\right)$ was lower than the critical concentration $\left(10^{-7} \mathrm{M}\right)$ at which sFlt-1 expression in the cultured vascular endothelial cells was increased in vitro. We previously showed that intravenous administration of anti-CF6 antibody to the rats counteracted its biological effects. ${ }^{7}$ Therefore, CF6 is active in vivo at lower concentrations compared with the effective one in vitro. CF6 seems to function as a novel stimulator of sFlt-1 in vivo.

We clearly showed that the plasma level of sFlt-1 was increased in TG mice. However, it is unclear whether the circulating sFlt-1 is mainly derived from vascular endothelial cells. We chose human elongation factor $1 \alpha$ as the promoter of the N-terminal portion of human carcitonin/CF6 fused gene in order to achieve CF6 gene expression in overall tissues, including the cardiovascular system. Indeed, it was confirmed that the gene expression of CF6 is upregulated by twofold in overall tissues in TG mice. Further examination is needed to determine the origin of the circulating sFlt-1 in TG mice. In contrast, the TG mice manifested the phenotype of elevation of systolic arterial blood pressure. Therefore, it is likely that cardiovascular risk is increased in TG mice.

\section{Regulation mechanism for sFlt-1 gene expression}

The tyrosine kinase c-Src is a key enzyme regulating a number of downstream effectors related to vasoconstriction. ${ }^{19}$ We recently showed that CF6 stimulates ATPase activity at the cell surface of HUVEC after binding to the $\beta$-subunit of plasma membrane ATP synthase and induces intracellular acidosis by a transient flux of hydrogen ion through $\mathrm{F}_{0}{ }^{12}$ As c-Src becomes activated by acidification, ${ }^{18}$ we previously investigated the linkage of CF6 to c-Src activation and showed that CF6 activated c-Src in HUVEC. ${ }^{17}$ Using PP1, a specific inhibitor of c-Src, and efrapeptin, a specific inhibitor for ATPase, we examined whether c-Src contributes to the increase in sFlt1 expression in HUVEC. Efrapeptin inhibited the CF6-induced increase in sFlt-1 expression by blocking intracellular acidosis and c-Src activation. PP1 inhibited the CF6-induced increase in sFlt-1 expression by blocking c-Src activation without affecting induction of intracellular acidosis. ${ }^{17}$ These suggest that CF6 increased the gene and protein expression of sFlt-1 through intracellular acidosis and c-Src activation in HUVEC.
It was reported that treatment of endothelial cells with statins upregulated the release of heme oxygenase- 1 and inhibited the release of sFlt-1. ${ }^{20}$ The addition of simvastatin, fluvastatin or mevastatin significantly decreased the basal production and VEGF-E-induced release of sFlt-1 from endothelial cells. As statins counteract against the production of reactive oxygen species, the release of sFlt-1 may be associated with the redox-sensitive signaling pathway. It is proposed that redox state per se may be involved in sFlt-1 expression upstream of c-Src in vascular endothelial cells. Further examination is needed to clarify this.

\section{Implications of linkage between CF6 and sFlt-1 in cardiovascular disorders}

In addition to its inhibitory effects on prostacyclin and NO, ${ }^{8} \mathrm{CF} 6$ was first shown to be involved in endothelial dysfunction by increasing the release of sFlt-1. The plasma level of sFlt-1 is increased in patients with hypertension and acute coronary syndromes, ${ }^{21}$ and these states are closely related to the presence of endothelial dysfunction. It was reported that the administration of recombinant sFlt-1 or a VEGFneutralizing antibody results in glomerular endothelial cell damage and proteinuria in rats, ${ }^{22}$ and adenoviral delivery of sFlt- 1 to pregnant rats mimics the clinical manifestations of preeclampsia. ${ }^{23}$ These suggest that the excess circulating sFlt-1 plays a role in the pathogenesis of atherosclerosis.

In clinical settings, the plasma level of CF6 was increased in human hypertension, ${ }^{24}$ end-stage renal disease ${ }^{25}$ and type 2 diabetes mellitus ${ }^{26}$ by $1.5-3.0$-fold compared with that in normal subjects. Furthermore, it was modulated by salt intake, and the percent change in plasma CF6 level was negatively correlated with that in plasma NO metabolite level. ${ }^{24}$ In patients with end-stage renal disease, the plasma level of CF6 was related to the development of ischemic heart disease. ${ }^{25}$ All these suggest that CF6 plays an important role in the genesis and progression of cardiovascular disorders, operating as a potent proatherogenic molecule. As CF6 generation is regulated by the nuclear factor- $\kappa \mathrm{B}$ signaling pathway, ${ }^{27-29} \mathrm{CF} 6$ seems to be associated with the development of atherosclerosis synergistically with other inflammatory compounds that are regulated by nuclear factor- $\kappa \mathrm{B}$ signaling.

In conclusion, this report first shows that CF6 might increase sFlt-1 release through the activation of c-Src in vascular endothelial cells. As sFlt-1 antagonizes the effect of VEGF as a promoter of angiogenesis, $\mathrm{NO}$ and prostacyclin, CF6 may be involved in the regulation of vascular homeostasis under physiological and pathological conditions. In light of these findings, CF6 seems to play an important role in the initiation and progression of atherosclerosis by the complex mechanisms including sFlt-1.

1 Morbidelli L, Chang CH, Douglus JG, Glanger HJ, Ledda F, Ziche M. Nitric oxide mediates mitogenic effect of VEGF on coronary venular endothelium. Am J Physiol 1996; 270: H411-H415.

2 Han He, Venema VJ, Gu X, Venema RC, Mario MB, Caldwell RB. Vascular endothelial growth factor signals endothelial cell production of nitric oxide and prostacyclin through flk-1/KDR activation of c-Src. J Biol Chem 1999; 274: 25130-25135.

3 Shibuya M. Vascular endothelial growth factor receptor-1 (VEGFR-1/FIt-1): a dual regulator for angiogenesis. Angiogenesis 2006; 9: 225-230.

4 Hornig C, Barleon B, Ahmad S, Vuorela P, Ahmed A, Weich HA. Release and complex formation of soluble VEGFR-1 from endothelial cells and biological fluids. Lab Invest 2000; 80: 443-454.

5 Richard DE, Berra E, Pouysségur J. Nonhypoxic pathway mediates the induction of hypoxia-inducible factor 1 a in vascular smooth muscle cells. J Biol Chem 2000; 275: 26765-26771. 
6 Page EL, Robitaille GA, Pouyssegur J, Richard DE. Induction of hypoxia-inducible factor-1alpha by transcriptional and translational mechanisms. J Biol Chem 2002; 277: 48403-48409.

7 Osanai T, Tanaka M, Kamada T, Nakano T, Takahashi K, Okada S, Sirato K, Magota K, Kodama S, Okumura K. Mitochondrial coupling factor 6 as a novel endogenous vasoconstrictor. J Clin Invest 2001; 108: 1023-1030.

8 Osanai T, Kamada T, Fujiwara N, Katoh T, Takahashi K, Kimura M, Satoh K, Magota K, Kodama S, Tanaka T, Okumura K. A novel inhibitory effect on prostacyclin synthesis of coupling factor 6 extracted from the heart of spontaneously hypertensive rats. J Biol Chem 1998; 273: 31778-31783.

9 Tanaka M, Osanai T, Murakami R, Sasaki S, Tomita H, Maeda N, Satoh K, Magota K, Okumura K. Effect of vasoconstrictor coupling factor 6 on gene expression profile in human vascular endothelial cells: enhanced release of asymmetric dimethylarginine. $J$ Hypertens 2006; 24: 489-497.

10 Moser TL, Stack MS, Schnaper HW, Asplin I, Enghild JJ, Højrup P, Everitt L, Hubchak S, Pizzo SV. Angiostatin binds ATP synthase on the surface of human endothelial cells. Proc Natl Acad Sci USA 1999; 96: 2811-2816.

11 Moser TL, Kenan DJ, Ashley TA, Roy JA, Goodman MD, Misra UK, Cheek DJ, Pizzo SV. Endothelial cell surface $F_{1}-F_{0}$ ATP synthase is active in ATP synthesis and is inhibited by angiostatin. Proc Natl Acad Sci USA 2001; 98: 6656-6661.

12 Osanai T, Magota K, Tanaka M, Shimada M, Murakami R, Sasaki S, Tomita H, Maeda N, Okumura K. Intracellular signaling for vasoconstrictor coupling factor 6 : novel function of $\beta$-subunit of ATP synthase as receptor. Hypertension 2005; 46: 1140-1146.

13 Matsumoto H, Rogi T, Yamashiro K, Takio K, Kodama S, Tsuruoka N, Hattori A, Mizutani S, Tsujimoto M. Characterization of a recombinant soluble form of human placental leucine aminopeptidase/oxytocinase expressed in Chinese hamster ovary cells. Eur J Biochem 2000; 267: 46-52.

$14 \mathrm{Li} \mathrm{H}$, Gu B, Zhang Y, Lewis DF, Wang Y. Hypoxia-induced increase in soluble Flt-1 production correlates with enhanced oxidative stress in trophoblast cells from the human placenta. Placenta 2005; 26: 210-217.

15 Nevo O, Soleymanlou N, Caniggia I, Wu Y, Xu J, Kingdom J, Many A, Zamudio S. Increased expression of SFlt-1 in in vivo and in vitro models of human placental hypoxia is mediated by HIF-1. Am J Physiol 2006; 291: R1085-R1093.

16 Itoh H, Nasu K, Matsumoto H, Kawano Y, Yoshimatsu J, Narahara H. Hypoxia regulates vascular endothelial growth factor and soluble fms-like tyrosine kinase-1 secretion by human oviductal epithelial cells and stromal fibroblasts. Fertil Steril 2006; 85: 1097-1102.

17 Kumagai A, Osanai T, Katoh C, Tanaka M, Tomita H, Morimoto T, Murakami R, Magota $\mathrm{K}$, Okumura K. Coupling factor 6 downregulates platelet endothelial cell adhesion molecule-1 via c-Src activation and acts as a proatherogenic molecule. Atherosclerosis 2008; 200: 45-50.
18 He Y, Smith SK, Day KA, Clark DE, Licence DR, Charnock-Jones DS. Alternative splicing of vascular endothelial growth factor (VEGF)-R1 (FLT-1) pre-mRNA is important for the regulation of VEGF activity. Mol Endocrinol 1999; 13: 537-545.

19 Ward JPT, Knock GA, Snetkov VA, Aaronson PI. Protein kinases in vascular smooth muscle tone-role in the pulmonary vasculature and hypoxic pulmonary vasoconstriction. Pharmacol Ther 2004; 104: 207-231.

20 Cudmore M, Ahmad S, Al-Ani B, Fujisawa T, Coxall H, Chudasama K, Devey LR, Wigmore SJ, Abbas A, Hewett PW, Ahmed A. Negative regulation of soluble Flt-1 and soluble endoglin release by heme oxygenase-1. Circulation 2007; 115: 1789-1797.

21 Schnabel R, Lubos M, Messow C, Sinnig C, Rupprecht H-J, Espinola-Klein C, Bicker C, Lackner KJ, Peetz D, Tiret L, Blankenberg S. Soluble Flt-1 as an early diagnostic marker in acute coronary syndromes: results from the AtheroGene study. Eur Heart J 2008; 29: 649-657.

22 Sugimoto H, Hamano Y, Kalluri R, Charytan D, Cosgrove D, Kieran M, Sudhakar A. Neutralization of circulating vascular endothelial growth factor (VEGF) by anti-VEGF antibodies and soluble VEGF receptor 1 (sFIt-1) induces proteinuria. J Biol Chem 2003; 278: 12605-12608.

23 Maynard SE, Min JY, Sukhatme VP, Merchan J, Lim KH, Li J, Mondal S, Libermann TA, Morgan JP, Sellke FW, Stillman IE, Epstein FH, Karumanchi SA. Excess placental soluble fms-like tyrosine kinase 1 (sFlt1) may contribute to endothelial dysfunction, hypertension, and proteinuria in preeclampsia. J Clin Invest 2003; 111: 649-658.

24 Osanai T, Sasaki S, Kamada T, Fujiwara N, Nakano T, Tomita H, Matsunaga T, Magota K, Okumura K. Circulating coupling factor 6 in human hypertension: role of reactive oxygen species. J Hypertens 2003; 21: 2323-2328.

25 Osanai T, Nakamura M, Sasaki S, Tomita H, Saitoh M, Osawa H, Yamabe H, Murakami $\mathrm{S}$, Magota K, Okumura K. Plasma concentration of coupling factor 6 and cardiovascular events in patients with end-stage renal disease. Kidney Int 2003; 64: 2291-2297.

26 Li XL, Xing QC, Dong B, Gao YY, Xing SS, Pang YZ, Jiang HF, Tang CS. Plasma level of mitochondrial coupling factor 6 increases in patients with type 2 diabetes mellitus. Int J Cardiol 2007; 117: 411-412.

27 Osanai T, Okada S, Sirato K, Nakano T, Saitoh M, Magota K, Okumura K. Mitochondrial coupling factor 6 is present on the surface of human vascular endothelial cells and released by shear stress. Circulation 2001; 104: 3132-3136.

28 Sasaki S, Osanai T, Tomita H, Matsunaga T, Magota K, Okumura K. Tumor necrosis factor $\alpha$ as an endogenous stimulator for circulating coupling factor 6 . Cardiovasc Res 2004; 62: 578-586.

29 Tomita H, Osanai T, Toki T, Sasaki S, Maeda N, Murakami R, Magota K, Yasujima M, Okumura K. Troglitazone and 15-deoxy delta ${ }^{12,14}$-prostaglandin $\mathrm{J}_{2}$ inhibit shearinduced coupling factor 6 release in endothelial cells. Cardiovasc Res 2005; 67 : 134-141. 